\title{
Maria Forlicz
}

Uniwersytet Ekonomiczny we Wrocławiu

\section{Tomasz Rólczyński, Julita Markiewicz-Patkowska}

Wyższa Szkoła Bankowa we Wrocławiu

e-mails:mforlicz@ue.wroc.pl; tomasz.rolczynski@gmail.com

\section{CHARAKTER ZAGROŻEŃ W RUCHU TURYSTYCZNYM A SKLONNOŚĆ DO UBEZPIECZANIA SIE}

\section{TRAVEL HAZARD CHARACTERISTICS \\ AND WILLINGNESS TO BUY TRAVEL INSURANCE POLICIES}

DOI: $10.15611 /$ pn.2017.500.02

JEL Classification: D01, D11, G22, D91

Streszczenie: Celem niniejszego artykułu jest ocena związku pomiędzy otrzymaniem informacji o zagrożeniach (naturalnych lub związanych z działalnością człowieka) występujących w pewnym regionie turystycznym a chęcią zwiększenia swojej ochrony ubezpieczeniowej. Sformułowano hipotezę, że skłonność do nabywania dodatkowego ubezpieczenia turystycznego jest inna w przypadku oczekiwania ataku terrorystycznego na terenie, do którego się podróżuje, niż w przypadku, gdy spodziewa się zagrożenia naturalnego. Otrzymane wyniki wskazują, że charakter zagrożeń nie ma kluczowego wpływu na chęć do wykupienia dodatkowego ubezpieczenia. Ponadto zaobserwowano, że po podaniu informacji o zagrożeniach odsetek chętnych do dodatkowego ubezpieczenia zwiększył się statystycznie istotnie tylko w przypadku zagrożeń umiarkowanie wysokich zarówno naturalnych, jak i terrorystycznych.

Słowa kluczowe: ryzyko, ubezpieczenia, zagrożenie turystyczne, rynek usług turystycznych.

Summary: The aim of the paper is to assess the relationship between obtaining information about hazards (natural or terroristic) appearing in certain touristic region and willingness to increase insurance coverage. A hypothesis was put forward that willingness to buy additional travel insurance policy is different in case of expected terrorist threat from that in case of expected natural threat. Results show that the kind of travel hazard does not influence propensity to buy additional travel policy. Moreover, it was observed that only in case of obtaining information about relatively high probalility of any kind of treat the percentage of subjects willing to buy additional policy was increased.

Keywords: risk, insurance, travel hazards, tourist market. 


\section{Wstęp}

Opierając się na teorii oczekiwanej użyteczności oraz zakładanej preferencji pewnych strat nad niepewnymi stratami o tej samej wielkości oczekiwanej [Friedman, Savage 1948; Arrow 1963], sformułowano teorię popytu na ubezpieczenie (produkt ubezpieczeniowy), która mówi, że celem każdej polisy ubezpieczeniowej jest przekształcenie niepewnej, ale potencjalnie dużej straty w stratę małą, ale pewną [Newhouse 1978, s. 19].

Zakład ubezpieczeń kalkuluje składkę tak, aby składka czysta wystarczyła na pokrycie szkód, czyli była równa sumie oczekiwanych odszkodowań, a dodatki do składki czystej zapewniały m.in. zysk i pokrycie kosztów działalności, więc aby doszło do zawarcia umowy ubezpieczenia, osoby fizyczne powinny zaakceptować cenę ubezpieczenia przewyższającą wartość oczekiwaną szkody (liczoną jako wartość przedmiotu ubezpieczenia pomnożoną przez prawdopodobieństwo wystąpienia szkody lub przybliżoną średnią roczną wartością szkody w przeszłości). W tradycyjnym podejściu do teorii wyboru w warunkach ryzyka - teorii oczekiwanej użyteczności, uważa się, że zachowania ludzi są racjonalne (zgodnie z definicją jednostki racjonalnej - homo economicus), co oznacza, że są oni konsekwentni w swoich działaniach i dążą do maksymalizacji dobrobytu [Cieślak 2003, s. 44, 45]. Zakładając, że ludzie dla swoich osądów używają narzędzi teorii prawdopodobieństwa i statystyki, a także potrafią automatycznie aktualizować informacje o prawdopodobieństwie wraz z nabywaniem informacji, powinno to skutkować wybieraniem opcji o najwyższej wartości oczekiwanej (lecz jedynie zakładając liniową funkcję użyteczności pieniądza). Stąd w sytuacji, gdy cena ubezpieczenia przewyższa wartość oczekiwaną straty, ludzie nie powinni się ubezpieczać, a jednak często to robią. Takie zachowanie świadczy o awersji do ryzyka, która wynikać może z tego, że funkcja użyteczności pieniądza części osób nie jest liniowa, lecz wklęsła [Bernoulli 1954].

Celem niniejszego opracowania jest ocena związku pomiędzy otrzymaniem informacji o zagrożeniach (naturalnych lub związanych z działalnością człowieka) występujących w pewnym regionie turystycznym a chęcią zwiększenia swojej ochrony ubezpieczeniowej.

Sformułowano następującą hipotezę, mówiącą, że skłonność do nabywania dodatkowego ubezpieczenia turystycznego jest inna w przypadku oczekiwania ataku terrorystycznego na terenie, do którego się podróżuje, niż w przypadku, gdy spodziewa się zagrożenia naturalnego.

\section{Zagrożenia w ruchu turystycznym}

Branża turystyczna jest jedną z najszybciej rozwijających się gałęzi gospodarki na świecie, w tym także w Polsce, którą odwiedza ok. $16 \mathrm{mln}$ turystów zagranicznych, a ich wydatki sięgają ok. 13 mld euro. Udział turystyki w Produkcie Krajowym 
Brutto w Polsce wynosi $6 \%{ }^{1}$. W przypadku państw będących tzw. monokulturami turystycznymi, których gospodarka bardzo mocno uzależniona jest od tempa rozwoju i stabilności turystyki, branża ta generuje często więcej niż połowę PKB².

Najczęściej używaną przez naukowców definicją słowa „turystyka” jest ta, którą podaje Światowa Organizacja Turystyki (WTO) działająca przy ONZ: „turystyka obejmuje ogół czynności osób, które podróżują i przebywają w celach wypoczynkowych, służbowych lub innych nie dłużej niż rok bez przerwy poza swoim codziennym otoczeniem"'3. Wiele osób nie wyobraża sobie urlopu bez wyjazdu wakacyjnego poza granice swojego kraju. Wzrost cen ropy naftowej czy fluktuacje kursu walutowego wpływają na zmniejszenie wielkości ruchu turystycznego, bo wiąże się to często ze znacznym wzrostem kosztów takiego wyjazdu. Jednak największy wpływ na zmniejszenie dynamiki liczby przyjazdów turystycznych do danego miejsca mają wszelkie zagrożenia dla życia i zdrowia. Oprócz zagrożeń naturalnych, często trudnych do przewidzenia, takich jak np. trzęsienia ziemi, powodzie, pożary czy wybuchy epidemii, zasadniczym problemem jest jeszcze niestabilna sytuacja ekonomiczna i polityczna w danym miejscu. Istotnym zjawiskiem, mającym ogromny wpływ na rynek branży turystycznej i rozwijającym się w niebezpiecznie szybkim tempie, jest zjawisko terroryzmu. Różnice kulturowe między turystami a ludnością miejscową są coraz większe, a swobodny sposób zachowania się wielu turystów powoduje, że są oni idealnym celem dla radykalnych organizacji [Beirman 2003]. Turyści bywają w dużych skupiskach ludzkich, w miejscach, w których znajdują się popularne obiekty turystyczne, stając się tym samym idealnym obiektem ataków terrorystycznych. Co więcej, wszelkie akty terrorystyczne z udziałem turystów, zwłaszcza z Europy czy Ameryki Północnej, są szeroko komentowane na całym świecie, a to właśnie stanowi zasadniczy cel terrorystów - nagłośnienie medialne.

Według statystyk Światowej Organizacji Turystyki Narodów Zjednoczonych, roczna dynamika liczby przyjazdów turystycznych była ujemna w latach, w których wystąpiły poważne zagrożenia zarówno naturalne, jak i te związane z działaniami człowieka. Ruch turystyczny zmalał w 1982 r. na skutek niestabilnej sytuacji politycznej w wielu miejscach na świecie, kiedy to wybuchł konflikt o Falklandy, wprowadzono stan wojenny w Polsce czy rozpoczął się konflikt izraelsko-libański. W 2001 r. ogromny wpływ na branżę turystyczną, w skali całego globu, miały wydarzenia z 11 września. Zamach islamskich terrorystów w kurorcie Kuta na Bali w 2002 r., kiedy zginęło ok. 200 osób, wybuch wojny w Iranie w 2003 r., a także ataki bombowe w Londynie w $2005 \mathrm{r}$. zasadniczo wpłynęły na gospodarkę turystyczną początku XXI w. [Pawlicz 2012]. W latach 2003 i 2009 wpływ na zmniejszenie ruchu turystycznego do krajów azjatyckich miał wybuch epidemii SARS. Inne z zagrożeń, które w niedzielę 26 grudnia 2004 r. na wiele lat zmieniło gospodarkę

\footnotetext{
1 https://biznes.newseria.pl/news/turystyka-jedna-z,p1438272425 (6.04.2017).

2 www.wttc.org (30.03.2017).

3 http://icr.unwto.org/content/unwto-un-system (30.03.2017).
} 
turystyczną wielu azjatyckich krajów, miało trzęsienie ziemi na Oceanie Indyjskim, o hipocentrum $30 \mathrm{~km}$ pod powierzchnią Ziemi w rejonie zachodniego wybrzeża Sumatry, oceniane na 9,1 w skali Richtera. Fala tsunami spowodowała wielkie straty w wielu krajach Azji Południowo-Wschodniej, niszcząc infrastrukturę i zabijając prawie 230 tys. ludzi w Indonezji, Tajlandii, Birmie, Indiach i na Sri Lance. Niszczący żywioł dotarł także do wybrzeży Afryki, wyrządzając szkody w Somalii, Kenii, Tanzanii, Mali, na Madagaskarze, Malediwach i Seszelach ${ }^{4}$. Wśród zabitych i zaginionych było wielu turystów, przebywających na bożonarodzeniowych urlopach.

\section{Wpływ terroryzmu i zagrożeń naturalnych na ruch turystyczny}

Atak terrorystyczny na Nowy Jork, który nastąpił 11 września 2001 r., spowodował zmniejszenie liczby turystów odwiedzających USA o ok. milion osób, tj. 20\% (z ponad 50 mln turystów w 2000 r. do 41,218 mln turystów w 2003 r.). Wybuch drugiego powstania palestyńskiego spowodował zmniejszenie liczby turystów odwiedzających Izrael o prawie $65 \%$ (z 2,41 mln turystów w 2000 r. do $0,86 \mathrm{mln}$ w 2002 r.). Wpłynęło to także na całą turystykę na Bliskim Wschodzie [Mika, Faracik 2007].

Według danych Światowej Organizacji Turystyki Narodów Zjednoczonych, od 2011 r., kiedy w Egipcie nastała tzw. arabska wiosna, liczba turystów odwiedzających Egipt spadła z ponad 14 mln w 2010 r. do ok. 9 mln w 2015 r. Jak podaje raport Euromonitor International, w pierwszym kwartale 2016 r. do Egiptu wybrało się o 46\% mniej zagranicznych turystów niż w analogicznym okresie 2015 r. W związku z zabiciem 24 zwiedzających w Muzeum Bardo w Tunisie w marcu 2015 r., a następnie kilka miesięcy później 39 osób wypoczywających na plaży w kurorcie Susa, Tunezja odnotowała spadek liczby turystów z zagranicy o 20\% w I kwartale $2016 \mathrm{r}$. w stosunku do analogicznego okresu w 2005 r. Niestabilna sytuacja polityczna i zagrożenie terrorystyczne wpłynęły także na spadek ruchu turystycznego do Turcji, na poziomie $20-25 \% \mathrm{w}$ połowie $2016 \mathrm{r}^{5}$

W 2002 r. liczba przyjazdów zagranicznych do Indonezji wynosiła 5033 400, a po zamachu w kurorcie Kuta na wyspie Bali, kiedy to na skutek wybuchu bomby zginęły 202 osoby z ponad 20 krajów, spadła do 4467021 w 2003 r. W 2004 r. znowu zanotowano wzrost o ponad 850 tys. odwiedzających. Niestety tsunami, które nawiedziło Indonezję w grudniu 2004 r., ponownie wpłynęło na zmniejszenie ruchu turystycznego o prawie 5\% w 2005 r. W październiku 2005 r. ponownie doszło do eksplozji bomb, na skutek czego śmierć poniosło 26 osób, a 102 osoby zostały ranne. Spowodowało to spadek przyjazdów turystów z zagranicy o 10\% w $2006 \mathrm{r}$. w stosunku do 2004 r. Pokazuje to, jak wrażliwą gałęzią gospodarki jest turystyka ${ }^{6}$.

\footnotetext{
$4 \mathrm{http}: / /$ wiadomosci.onet.pl/kiosk/tsunami-jak-zarobic-na-tragedii/lfqlf (23.03.2017).

$5 \mathrm{http} / / /$ biznes.onet.pl/wiadomosci/turystyka/niegdys-byly-turystycznymi-mekkami-dzis-strach-tam-jezdzic/9cfte6 (5.04.2017).

${ }^{6}$ www.budpar.go.id (3.04.2017).
} 
Nawet pojedyncze akty terrorystyczne powodują, że wielu turystów rezygnuje $\mathrm{z}$ wyjazdów do tych miejsc, uznając je za narażone na zagrożenie terroryzmem, mimo że wcześniej spędzali tam wielokrotnie wakacje i czuli się bezpiecznie. Jednak A. Pizam i A. Fleischer stwierdzili, że gdy terrorystyczne zdarzenia nie są powtarzane, przemysł turystyczny odzyskiwał klientów w ciągu od sześciu do dwunastu miesięcy [Pizam, Fleischer 2002].

Zarówno zagrożenia związane z działalnością człowieka, takie jak np. zamachy terrorystyczne, jak i zagrożenia naturalne związane np. z wybuchami epidemii powodują spadek ruchu turystycznego $\mathrm{w}$ danym miejscu, $\mathrm{z}$ jednoczesnym wzrostem kwot wydawanych na ubezpieczenia zdrowotne. Ministerstwo Spraw Zagranicznych odradza podróżnym wyjazdy w miejsca, gdzie w danym momencie istnieje zwiększone prawdopodobieństwo zachorowania na groźne choroby?

Bez względu na to, czy wyjazd turystyczny odbywa się w obrębie Europy, czy poza nią, turyści zawsze mają możliwość wykupienia dodatkowego ubezpieczenia, gwarantującego np. koszty leczenia w kwocie adekwatnej do kosztów leczenia w danym kraju. Im uboższy kraj, tym niższy jest poziom świadczonych usług medycznych. Należy wtedy liczyć się np. z potrzebą transportu do innego, np. sąsiedniego kraju. W przypadku chorób tropikalnych zalecane jest czasami, aby nie wracać do kraju w trakcie choroby, ale przebyć cały proces leczenia w kraju, w którym wiedzą o sposobach jej leczenia i odpowiednie medykamenty są dobrze znane i bardziej dostępne niż we własnym kraju. W przypadku zachorowania np. na dengę podczas pobytu w Malezji czy Singapurze, lepiej przejść cały proces leczenia na miejscu, zamiast wracać do kraju. Wysoki poziom prywatnych usług medycznych i znajomość metod leczenia zapewnia najlepsze rokowania wyleczenia i szybkiego powrotu do zdrowia. Wiąże się to jednak z dużymi kosztami, na które należy być przygotowanym.

W 2017 r. ponad 4,2 mln Polaków (26\%) planowało wyjazd za granicę, a 12,3 mln (74 \%) zamierzało zorganizować swój wypoczynek w kraju, z czego aż $56 \%$ deklarowało, że samodzielnie zorganizuje swój wyjazd. Z oferty biur podróży planowało skorzystać 44\% osób, co stanowi spadek o 459 tys. w porównaniu z $2016 \mathrm{r}$. Obecnie najbardziej popularnym krajem na wakacyjne wyjazdy jest Hiszpania (z uwzględnieniem Wysp Kanaryjskich), stanowiąca aż 14\% celów wszystkich zagranicznych wyjazdów. Następnie - Chorwacja (14\%), Grecja (11\%) i Włochy (11\%). Popularne przez ostatnie lata i utrzymujące się na szczycie najpopularniejszych kierunków wakacyjnych takie kraje, jak Turcja czy Egipt, znalazły się poza pierwszą „dziesiątką". Polacy coraz częściej decydują się na samodzielne wyjazdy, a podczas pobytu zagranicą obawiają się najczęściej zamieszek, strajków, zamachów i aktów terroru (9\%), wypadków lub awarii (6\%) i problemów zdrowotnych (5\%). Osoby, które jednak wolą zorganizowaną formę wypoczynku, boją się najczęściej możliwości wystąpienia zamieszek, strajków, zamachów oraz aktów terroru (19\% - spadek

${ }^{7} \mathrm{http}: / /$ www.msz.gov.pl/pl/c/MOBILE/informacje_konsularne/ostrzezenia/ostrzezenia_dla_podrozujacych (27.06.2017). 
o 4 p.p.), obecności uchodźców/emigrantów ( $6 \%$ - spadek o 7 p.p.) oraz problemów zdrowotnych (także 5\%). 73\% Polaków (ponad 3 mln osób), którzy planują zagraniczne wakacje, zamierza wykupić ubezpieczenie turystyczne, co stanowi wzrost o 3 p.p. w stosunku do 2016 r. Dla porównania, jeszcze 4 lata temu, w 2013 r., tylko 58\% planujących zagraniczne wakacje zamierzało wykupić takie ubezpieczenie. Jak podaje Mondial Assistance, wiodący dostawca usług assistance oraz ubezpieczeń turystycznych w Polsce i na świecie, osoby, które najczęściej decydują się na wykupienie ubezpieczeń, to osoby z największych polskich miast, z wyższym wykształceniem, pomiędzy 30. a 49. rokiem życia, osiągające dochód na gospodarstwo domowe powyżej $3500 \mathrm{zt}^{8}$.

Polacy mają coraz większą świadomość na temat ubezpieczeń turystycznych i coraz częściej wykupują je na wyjazdy organizowane samodzielnie. Według danych z końca 2015 r. rynek ubezpieczeń turystycznych jest wart ok. $300 \mathrm{mln}$ zł i rośnie co roku o kilkanaście procent. Według ekspertów towarzystwa ubezpieczeniowego AXA świadomość na temat ubezpieczeń turystycznych rośnie. Turyści wykupują coraz więcej i coraz droższych polis, a także szukają różnych możliwości rozszerzenia ubezpieczeń. Biorąc pod uwagę niestabilną sytuację na świecie i ciągłe doniesienia o aktach terrorystycznych, nie tylko w krajach uchodzących za niebezpieczne, nie dziwi, że coraz więcej osób, udając się na urlop, pragnie zabezpieczyć siebie i swoich bliskich na wypadek nieprzewidzianych sytuacji. Zauważyć można nieznaczny wzrost zagrożeń związanych z możliwością zachorowania na choroby tropikalne czy zagrożenia katastrofami naturalnymi. Zmieniają się jednak świadomość przeciętnego turysty i rosnąca potrzeba bezpieczeństwa, a także świadomość szacowania ryzyka. Zarządzanie ryzykiem $\mathrm{w}$ turystyce jest zjawiskiem nowym w świadomości indywidualnego turysty 9 .

Z badań Mondial Assistance wynika, że 67\% osób z 15 mln planujących wakacje w 2017 r. deklarowało chęć zakupu polisy turystycznej. Polacy ubezpieczają się na coraz wyższe kwoty. Jeszcze kilka lat temu dominowała sprzedaż podstawowych polis na 10-20 tys. euro. Obecnie dominują polisy powyżej 30 tys. euro na koszty leczenia, a zdarzają się polisy nawet na 100 czy 150 tys. euro ${ }^{10}$. W praktyce ubezpieczeniowej do grupy ubezpieczeń związanych z turystyką dla klienta indywidualnego zalicza się ubezpieczenia [Jędrzychowska 2016]:

- następstw nieszczęśliwych wypadków (NNW),

- odpowiedzialności cywilnej (OC) - komunikacyjne i w życiu prywatnym,

- assistance,

- kosztów leczenia za granicą,

- kosztów akcji ratowniczej i poszukiwawczej,

$8 \mathrm{http} / / /$ www.mondial-assistance.pl/biznes/centrum-prasowe/Aktualnosci/plany_wakacyjne_polakow_assistance_ubezpieczenie_turystyczne.aspx (21.06.2017).

${ }_{9}$ http://turystyka.rp.pl/artykul/1231001.html (20.06.2017).

${ }^{10} \mathrm{http} / /$ www.mondial-assistance.pl/biznes/centrum-prasowe/Aktualnosci/plany_wakacyjne_polakow_assistance_ubezpieczenie_turystyczne.aspx (20.06.2017). 
- sprzętu sportowego i bagażu,

- kosztów rezygnacji z uczestnictwa w wyjeździe lub wcześniejszego powrotu.

Do powyższych ubezpieczeń zaliczyć również można obecne na polskim rynku ubezpieczenie od skutków ataków terrorystycznych.

Według gazety „Rzeczpospolita” (z 12.06.2016), 28\% badanych Polaków zadeklarowało, że wyjeżdżając na zagraniczne wakacje ,zawsze” wykupuje ubezpieczenie, a „czasami” ubezpiecza się 13\% respondentów. Ponad połowa Polaków nigdy nie wykupuje dodatkowej ochrony przed wyjazdem za granicę ${ }^{11}$. Klienci, którzy decydują się na zakup polisy, coraz częściej chcą się ubezpieczać także na wypadek terroryzmu, klasyfikowanego obecnie jako ryzyko, które można wycenić i od którego można się ubezpieczyć. Jak podaje Dział Ubezpieczeń Majątkowych AIG, jednym z podstawowych narzędzi do oceny ryzyka terrorystycznego są mapy zagrożenia terrorystycznego ${ }^{12}$. Niestety trudno do końca przewidzieć, gdzie może wydarzyć się akt terroru, który dzieje się nagle i niespodziewanie, a zagrożona lista miejsc na świecie stale się wydłuża.

Niektórzy ubezpieczyciele proponują tzw. klauzulę nieoczekiwanej wojny lub aktu terroru, czyli deklarację ubezpieczyciela, że poniesie odpowiedzialność za szkody będące skutkiem następstw nieszczęśliwych wypadków poniesionych w wyniku nagłego wybuchu wojny i aktów terroru, jednak nie dłużej niż kilka dni, zwykle około tygodnia. Klauzule oferują takie firmy ubezpieczeniowe, jak np. Signal Iduna, Generali, Allianz, AXA, jednak wiele krajów jest z niej wyłączonych, np. Afganistan, Arabia Saudyjska, Bangladesz, Gruzja, Irak, Jordania, Kolumbia, Pakistan, Rwanda czy Syria. Także turyści, którzy zdecydują się odbyć podróż do kraju, na którego terytorium wojna lub wojna domowa już trwa, nie zostają objęci tą klauzulą ${ }^{13}$.

\section{Metoda badawcza oraz wyniki badań}

W celu weryfikacji hipotezy postawionej na wstępie przeprowadzono eksperyment.

\section{Badanie}

Badanie przeprowadzono wśród 353 studentów Uniwersytetu Ekonomicznego we Wrocławiu oraz Wyższej Szkoły Bankowej we Wrocławiu, głównie studiów niestacjonarnych. Około $80 \%$ badanych stanowiły kobiety. Średni wiek badanych wyniósł 23 lata.

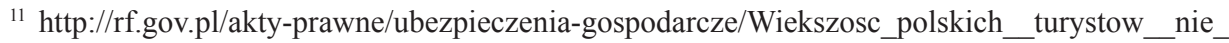
kupuje_dodatkowych_ubezpieczen_na_wyjazd_zagraniczny_22361 (21.06.2017).

${ }_{12}$ https://www.obserwatorfinansowy.pl/tematyka/rynki-finansowe/firmy-szukaja-nowych-ubezpieczen/ (21.06.2017).

${ }^{13} \mathrm{https}$ ://www.polisaturystyczna.pl/poradniki/jak-ubezpieczyc-sie-od-ryzyka-dzialan-wojennych-zamieszek-i-aktow-terroru (20.06.2012). 


\section{Metoda badawcza}

Badanych podzielono na pięć grup. W każdej grupie odtworzono tę samą prezentację, która przedstawiała ofertę pobytu w hotelu położonym w egzotycznym miejscu. Po obejrzeniu prezentacji każdy badany otrzymał do wypełnienia formularz. Składał się on z sześciu pytań i tylko jedno (pytanie czwarte) różniło się w poszczególnych grupach. Pytania pierwsze i czwarte dotyczyły oceny atrakcyjności przedstawionej oferty, pytania drugie i piąte miały na celu dowiedzenie się, ile badani byliby skłonni zapłacić za wycieczkę, a pytania trzecie i szóste skupiały się na tym, czy badany byłby skłonny wykupić dodatkowe ubezpieczenie. Pytania od pierwszego do trzeciego nie ujawniały, jaka sytuacja występuje w danym rejonie, taką wiedzę zdobywali badani dopiero w pytaniu czwartym. $\mathrm{Z}$ wiedzy tej mieli również skorzystać w pytaniach piątym i szóstym (patrz formularz w Załączniku). Warianty informacji podanych w poszczególnych grupach opisane zostały w tab. 1 .

Tabela 1. Warianty czwartego pytania w kwestionariuszu

\begin{tabular}{|l|l|}
\hline Scenariusz & Założenia scenariusza \\
\hline $\begin{array}{l}\text { A Kod } \\
\text { UWT })\end{array}$ & $\begin{array}{l}\text { Z informacji Ministerstwa Spraw Zagranicznych wynika, że w regionie podróży } \\
\text { występuje umiarkowanie wysokie zagrożenie terrorystyczne. Prosimy Cię o ponowną } \\
\text { ocenę tej oferty. }\end{array}$ \\
\hline $\begin{array}{l}\text { B } \\
\text { Kod }\end{array}$ & $\begin{array}{l}\text { Z informacji Ministerstwa Spraw Zagranicznych wynika, że w regionie podróży wy- } \\
\text { stępuje umiarkowanie wysokie zagrożenie trzęsieniem ziemi lub tsunami. Prosimy Cię } \\
\text { o ponowną ocenę tej oferty. }\end{array}$ \\
\hline $\begin{array}{l}\text { C } \\
(\text { KodBZ) }\end{array}$ & $\begin{array}{l}\text { Z informacji Ministerstwa Spraw Zagranicznych wynika, że w regionie podróży nie } \\
\text { występuje zagrożenie trzęsieniem ziemi i tsunami ani zagrożenie terrorystyczne. Prosi- } \\
\text { my Cię o ponowną ocenę tej oferty. }\end{array}$ \\
\hline $\begin{array}{l}\text { D } \\
\text { Kod UNT) }\end{array}$ & $\begin{array}{l}\text { Z informacji Ministerstwa Spraw Zagranicznych wynika, że w regionie podróży wy- } \\
\text { stępuje umiarkowanie niskie zagrożenie terrorystyczne. Prosimy Cię o ponowną ocenę } \\
\text { tej oferty. }\end{array}$ \\
\hline $\begin{array}{l}\text { E } \\
\text { Kod UNN) }\end{array}$ & $\begin{array}{l}\text { Z informacji Ministerstwa Spraw Zagranicznych wynika, że w regionie podróży wy- } \\
\text { stępumiarkowanie niskie zagrożenie trzęsieniem ziemi lub tsunami. Prosimy Cię } \\
\text { o ponowną ocenę tej oferty. }\end{array}$ \\
\hline
\end{tabular}

Źródło: opracowanie własne.

\section{Wyniki}

$\mathrm{Na}$ wstępie wyliczono procent osób skłonnych się ubezpieczyć dodatkowo w każdej z podgrup przed podaniem informacji o zagrożeniach, a następnie procent osób skłonnych się dodatkowo ubezpieczyć w każdej z podgrup po podaniu informacji o zagrożeniach.

Różnice pomiędzy odsetkami osób chcącymi się dodatkowo ubezpieczyć w różnych grupach przed podaniem dodatkowej informacji wydają się duże, dlatego sprawdzono, czy różnice te są statystycznie istotne. Najniższy poziom wartości $p$ otrzymany dla pary scenariuszy UNN i UNT wyniósł 0,1883, dlatego można sądzić, że odsetki we wszystkich grupach przed podaniem dodatkowych informacji były 
równe. W kolejnym kroku sprawdzono, czy podanie informacji o zagrożeniu (lub jego braku) wpłynęło istotnie na chęć do wykupienia dodatkowego ubezpieczenia (czy odsetek osób chcących wykupić dodatkowe ubezpieczenie był różny w danej podgrupie przed i po podaniu informacji). Wyniki tych obliczeń zawiera tab. 2 .

Tabela 2. Procent osób chętnych się dodatkowo ubezpieczyć przed i po podaniu dodatkowej informacji oraz istotność różnicy między tymi odsetkami

\begin{tabular}{|l|c|c|c|c|}
\hline Kod & $\begin{array}{c}\text { Odsetek osób chętnych } \\
\text { do dodatkowego } \\
\text { ubezpieczenia } \\
\text { przed podaniem } \\
\text { informacji } \\
\text { o zagrożeniach }\end{array}$ & $\begin{array}{c}\text { Odsetek osób chętnych } \\
\text { do dodatkowego } \\
\text { ubezpieczenia po podaniu } \\
\text { informacji o zagrożeniach }\end{array}$ & $\begin{array}{c}\text { Liczba } \\
\text { obserwacji } \\
\text { danej grupie }\end{array}$ & $\begin{array}{c}p \text {-value dla testu } \\
\text { dwustronnego } \\
\text { dla } p\end{array}$ \\
\hline BZ & 0,6410256 & 0,5256410 & 78 & 0,1439 \\
\hline UNN & 0,6875000 & 0,6718750 & 64 & 0,8498 \\
\hline UNT & 0,5686275 & 0,6274510 & 51 & 0,5446 \\
\hline UWN & 0,5842697 & 0,8089888 & 89 & 0,0011 \\
\hline UWT & 0,6666667 & 0,8421053 & 57 & 0,0296 \\
\hline
\end{tabular}

Źródło: opracowanie własne na podstawie badań własnych.

Podanie informacji o braku zagrożeń terrorystycznych i naturalnych w rejonie spowodowało spadek odsetka osób chętnych się dodatkowo ubezpieczyć, jednakże spadek ten nie był istotny statystycznie. Podanie informacji o umiarkowanie niskim zagrożeniu (bez względu na typ) nie spowodowało istotnych zmian w odsetku osób chcących wykupić dodatkowe ubezpieczenie. Jedynie informacja o występowaniu umiarkowanie wysokiego zagrożenia (ponownie bez względu na charakter zagrożenia) spowodowała istotny wzrost badanego odsetka. Wśród badanych zdarzyły się przypadki, gdy dana osoba po otrzymaniu dodatkowej informacji rezygnowała $\mathrm{z}$ ubezpieczenia (mimo że podano, że występuje pewne zagrożenie) obliczono również, jaki procent osób, spośród tych, które nie chciały się dodatkowo ubezpieczyć przed podaniem informacji, decydował się jednak na ubezpieczenie po jej przeczytaniu. Wyniki tych obliczeń zawiera tab. 3.

Tabela 3. Procent osób spośród tych, które w pytaniu trzecim odpowiadały „nie”, które w pytaniu szóstym odpowiedziały „tak”

\begin{tabular}{|l|c|c|}
\hline \multicolumn{1}{|c|}{ Rodzaj zagrożenia } & Liczba osób & Odsetek \\
\hline BZ & 78 & 0,00 \\
\hline UNN & 64 & 6,25 \\
\hline UNT & 51 & 15,69 \\
\hline UWN & 89 & 24,72 \\
\hline UWT & 57 & 21,05 \\
\hline
\end{tabular}

Źródło: opracowanie własne na podstawie badań własnych. 
Największy wzrost odsetka osób, które zmieniły zdanie na korzyść wykupienia dodatkowego ubezpieczenia nastąpił w przypadku podania informacji o umiarkowanie wysokim zagrożeniu naturalnym. Statystycznie odsetek ten nie różnił się jednak od analogicznego odsetka wyliczonego dla grupy, która otrzymała informację o wysokim zagrożeniu terrorystycznym $(p=0,6091)$. Wystąpiła natomiast istotna różnica pomiędzy odsetkiem osób, które zmieniły zdanie na korzyść wykupienia dodatkowego ubezpieczenia w przypadku informacji o niskim zagrożeniu naturalnym i terrorystycznym $(p=0,0000)$. Ponadto odsetek osób, które zmieniły zdanie dla pary, nie różni się istotnie dla pary UNT i UWT ( $p=0,4735)$, ale różni się dla pary UNN i UWN $(p=0,0000)$. Nasuwa się wniosek, że badani reagują z dużą wrażliwością na informację o jakimkolwiek zagrożeniu terrorystycznym (niskim czy wysokim), natomiast informacja o niskim zagrożeniu naturalnym nie jest już tak silnym bodźcem do dodatkowego ubezpieczenia się.

Po otrzymaniu informacji o braku zagrożeń z ubezpieczenia zrezygnowało $11,39 \%$. Świadczyć to może, że część osób, nie posiadając żadnej informacji o zagrożeniach, zakładała, że jednak jakieś występują w rejonie podróży. Może to być przyczyną słabego wzrostu odsetka osób chętnych się dodatkowo ubezpieczyć w scenariuszach UNN i UNT.

\section{Zakończenie}

Podsumowując wyniki badania, można stwierdzić, że charakter zagrożeń nie ma kluczowego wpływu na chęć do wykupienia dodatkowego ubezpieczenia. Zaobserwowano natomiast (choć nie było to obiektem badań), że osoby skłonne do wykupienia dodatkowego ubezpieczenia były też skłonne zapłacić więcej za wycieczkę we wszystkich przypadkach przed podaniem informacji o zagrożeniu i prawie wszystkich przypadkach po podaniu informacji o zagrożeniu (wyjątki stanowił scenariusz UNN). Po podaniu informacji o zagrożeniach odsetek chętnych do dodatkowego ubezpieczenia zwiększył się, jednak statystycznie istotnie tylko w przypadku zagrożeń umiarkowanie wysokich zarówno naturalnych, jak i terrorystycznych (odsetek zmniejszył się w próbie po podaniu informacji, że występuje brak zagrożeń, ale statystycznie nieistotnie).

\section{Literatura}

Arrow K.J., 1963, Uncertainty and the welfare economics of medical care, American Economic Review, vol. 53, s. 941-973.

Beirman D., 2003, Restoring Tourism Destinations in Crisis: A Strategic Marketing Approach, Allen and Unwin, Sydney.

Bernoulli D., 1954, Exposition of a new theory on the measurement of risk, Econometrica, vol. 22, no. 1 , s. 23-36. 
Cieślak A., 2003, Behawioralna ekonomia finansowa. Modyfikacja paradygmatów funkcjonujących w nowoczesnej teorii finansów, Materiały i Studia NBP, z. 165.

Friedman M., Savage L.J., 1948, The utility analysis of choices involving risk, Journal of Political Economy, vol. 56, s. 279-304.

Jędrzychowska A., 2016, Ubezpieczenia turystyczne, [w:] Ronka-Chmielowiec W. (red.), Ubezpieczenia, C.H. Beck, Warszawa, s. 441-450.

Mika M., Faracik R., 2007, Międzynarodowy ruch turystyczny, [w]: Kurek W. (red.), Turystyka, Wydawnictwo Naukowe PWN, Warszawa.

Newhouse J.P., 1978, The Economics of Medical Care: A Policy Perspective, Addison-Wesley.

Pawlicz A., 2012, Zarzadzanie kryzysowe w turystyce na poziomie lokalnym na przykładzie skażenia wody morskiej w Świnoujściu w sierpniu 2010 roku, Zeszyty Naukowe. Szkoła Główna Handlowa. Kolegium Gospodarki Światowej, vol. 35, s. 157-171.

Pizam A., Fleischer A., 2002, Severity vs. frequency of acts of terrorism: Which has a larger impact on Tourism Demand?, Journal of Travel Research, vol. 40, no. 3, s. 337-339.

\section{Źródla internetowe}

http://biznes.onet.pl/wiadomosci/turystyka/niegdys-byly-turystycznymi-mekkami-dzis-strach-tamjezdzic/9cfte6 (5.04.2017).

http://icr.unwto.org/content/unwto-un-system (30.03.2017).

http://rf.gov.pl/akty-prawne/ubezpieczenia-gospodarcze/Wiekszosc_polskich_turystow_nie_kupu-

je_dodatkowych_ubezpieczen_na_wyjazd_zagraniczny_22361 (21.06.2017).

http://turystyka.rp.pl/artykul/1231001.'̄tml (20.06.2017).

$\mathrm{http} / / /$ wiadomosci.onet.pl/kiosk/tsunami-jak-zarobic-na-tragedii/lfqlf (23.03.2017).

http://www.mondial-assistance.pl/biznes/centrum-prasowe/Aktualnosci/plany_wakacyjne_polakow_ assistance_ubezpieczenie_turystyczne.aspx (20.06.2017).

http://www.mondial-assistance.pl/biznes/centrum-prasowe/Aktualnosci/plany_wakacyjne_polakow_ assistance ubezpieczenie turystyczne.aspx (21.06.2017).

http://www.msz.gov.pl/pl/c/MOBILE/informacje_konsularne/ostrzezenia/ostrzezenia_dla_podrozujacych (27.06.2017).

https://biznes.newseria.pl/news/turystyka-jedna-z,p1438272425 (6.04.2017).

https://pl.wikipedia.org/wiki/SARS

https://www.obserwatorfinansowy.pl/tematyka/rynki-finansowe/firmy-szukaja-nowych-ubezpieczen/ (21.06.2017).

https://www.polisaturystyczna.pl/poradniki/jak-ubezpieczyc-sie-od-ryzyka-dzialan-wojennych-zamieszek-i-aktow-terroru (20.06.2012).

www.budpar.go.id (3.04.2017).

www.wttc.org (30.03.2017). 


\section{Załącznik}

\section{Pytanie 1}

Obejrzałeś właśnie prezentację pewnej oferty wyjazdowej. Bardzo prosimy Cię o ocenienie atrakcyjności przedstawionego celu podróży. Wpisz X w odpowiednią kratkę.

\begin{tabular}{|c|c|c|c|c|c|c|}
\hline $\begin{array}{c}\text { Całkowicie } \\
\text { nieatrakcyjny }\end{array}$ & $\begin{array}{c}\text { Bardzo mało } \\
\text { interesujący }\end{array}$ & $\begin{array}{c}\text { Mało } \\
\text { interesujący }\end{array}$ & Przeciętny & $\begin{array}{c}\text { Dość } \\
\text { atrakcyjny }\end{array}$ & Atrakcyjny & $\begin{array}{c}\text { Bardzo } \\
\text { atrakcyjny }\end{array}$ \\
\hline & & & & & & \\
\hline
\end{tabular}

\section{Pytanie 2}

Ile byłbyś skłonny zapłacić za dwutygodniowy wyjazd do tego hotelu (łącznie z przelotem, ubezpieczeniem podstawowym i opieką pilota rezydenta)? Podaj cenę za jedną osobę w pokoju dwuosobowym.

\section{Pytanie 3}

Podstawowy pakiet ubezpieczenia na czas takiego wyjazdu pokrywa koszty leczenia do kwoty 30000 euro, suma ubezpieczenia następstw nieszczęśliwych wypadków to 3500 euro. Czy byłbyś skłonny wykupić dodatkowe ubezpieczenie podróżne pokrywające koszty leczenia do kwoty 60000 euro, następstw nieszczęśliwych wypadków 15000 euro za cenę 300 zł (około 70 euro) obejmujące między innymi pomoc lekarską, transport zwłok do kraju, pobyt w szpitalu i pomoc lekarzy specjalistów?

\section{Pytanie 5}

Po otrzymaniu powyższej informacji odpowiedz ponownie na pytanie ile byłbyś skłonny zapłacić za dwutygodniowy wyjazd do tego hotelu (łącznie z przelotem, ubezpieczeniem podstawowym i opieką pilota rezydenta) zdając sobie sprawę z występujących zagrożeń? Podaj cenę za jedną osobę w pokoju dwuosobowym.

\section{Pytanie 6}

Czy byłbyś skłonny wykupić dodatkowe ubezpieczenie podróżne pokrywające koszty leczenia do kwoty 60000 euro, następstw nieszczęśliwych wypadków 15000 euro za cenę 300 zł (około 70 euro) obejmujące między innymi pomoc lekarską, transport zwłok do kraju, pobyt w szpitalu i pomoc lekarzy specjalistów? 